\title{
Use of Assessment Indicators to Forecast Market Promotion of Products
}

\section{Anna V. Clopova, Petr V. Skripin, Tatiana I. Shpak, and Roman B. Zhukov}

Don State Agrarian University, faculty of biotechnology, 24, Krivoshlykova str., 346493, Persianovsky, Rostov region, Russia

\section{ORCID:}

Anna V. Clopova: http://orcid.org/0000-0002-1896-0267

\section{Abstract}

During recent years the trend to tighten competitiveness has been increasing globally almost in all industries, although before then it was absent in many countries and economic sectors. This article touches upon the main issues regarding the competitiveness of enriched curd products with prebiotic substances. On the basis of a consumer survey, the calculation of advantageous indicators was performed. According to the results of the ranking of quality indicators, the following maximum values were accepted: taste and smell, form and consistency, titratable acidity, amino

Corresponding Author: Anna V. Clopova

anna.clopova@yandex.ru

Published: 5 April 2021

Publishing services provided by Knowledge E

(c) Anna V. Clopova et al. This article is distributed under the terms of the Creative Commons Attribution License, which permits unrestricted use and redistribution provided that the original author and source are credited.

Selection and Peer-review under the responsibility of the DonAgro Conference Committee. acid composition, and vitamin and mineral composition. A comparative analysis of consumer qualities of curd products is given. According to the results of the assessment of the quality of curd products, it can be concluded that competitive advantage belongs to a curd product enriched with cedar oil cake, lactulose syrup and whey proteins. This is followed by the curd product enriched with cedar oil cake and lactulose syrup, and then the integral indicator in the curd sample enriched with cedar oil cake. The integral indicators of curd cream and curd cheese have low values: 0.16 and 0.145 , respectively. Thus, the developed curd products enriched with prebiotic substances will be in demand in the modern market of curd products.

Keywords: competitiveness, complex quality indicator, curd products, cedar oil cake, whey protein, lactulose

\section{Introduction}

During the recent years the trend to tighten the competitiveness is increasing globally almost in all industries. Although few years ago it was absent in many countries and sectors of economy. The positions in all markets were clearly defined and protected. [1; 3] Even where there was competition, it was not so fierce. The rise in competition was restrained by the direct intervention of various municipal bodies, governments, large cartels and companies. 
Competition, in its most general form, is the state of the market in which there is a very large number of buyers and sellers, while at the same time each of them occupies a relatively small market share and can not dictate the conditions for the sale and purchase of products. [10; 14] The presence of important and accessible information on prices, their dynamics, sellers and customers in a certain market is assumed not only in this place, but also in other regions and cities. The market of perfect competition implies the inaccessibility of producer power over the market and pricing not by producers, but by the function of supply and demand. [13; 14]

\section{Methods}

The assessment of competitiveness was performed for all developed curd products, using a well-known method $[1 ; 14]$. In order to assess the competitiveness of enriched curd products, the expert group selected the following indicators that quite fully characterize the quality of the types of curd products being compared: $X_{1}$ - taste and smell; $X_{2}$ - Form and consistency; $X_{3}$ - titratable acidity; $X_{4}$ - amino acid composition; $X_{5}$ - vitamin and mineral composition.

\section{Results}

According to the results of the ranking of quality indicators (Table 1), the following maximum values were accepted: $X_{1}$ - taste and smell - 5 points; $X_{2}$ - Form and consistency - 4 points; $X_{3}$ - titratable acidity - 3 points; $X_{4}$ - amino acid composition - 5 points; $X_{5}$ vitamin and mineral composition - 3 points.

The determination of the weight coefficients $\left(m_{i}\right)$ of curd products was carried out using the formula 1 :

$$
M_{i}=\frac{\sum_{i=1}^{r} M_{i j}}{\sum_{j=1}^{n} \sum M_{i j}},
$$

where, $\sum_{j=1}^{n} M_{i j}$ - the sum of the ranks of each indicator;

$\sum_{j=1}^{n} \sum M_{i j}$ the sum of the ranks of all indicators.

Thus, the following values of the weighting coefficients for each indicator were obtained by calculation, respectively: $\mathrm{m}_{1}=25: 100=0.25 ; \mathrm{m}_{2}=18: 100=0.18 ; \mathrm{m}_{3}=$ 17: $100=0.17 ; m_{4}=23: 100=0.23 ; m_{5}=17: 100=0.17$. However, for a more complete characterization of the competitiveness of products and goods, it is necessary to determine complex quality indicator. 
TABLE 1: Ranking results of quality indicators

\begin{tabular}{|c|c|c|c|c|c|c|}
\hline \multirow[t]{2}{*}{ Experts } & \multicolumn{5}{|c|}{ Qualities } & \multirow{2}{*}{$\begin{array}{l}\text { The sum of the } \\
\text { ranks of each } \\
\text { indicator } n \\
\sum M_{i j} j=1\end{array}$} \\
\hline & $X_{1}$ & $X_{2}$ & $x_{3}$ & $X_{4}$ & $X_{5}$ & \\
\hline 1 & 5 & 4 & 3 & 5 & 3 & 20 \\
\hline 2 & 5 & 3 & 4 & 4 & 4 & 20 \\
\hline 3 & 5 & 4 & 3 & 5 & 3 & 20 \\
\hline 4 & 5 & 4 & 3 & 4 & 4 & 20 \\
\hline 5 & 5 & 3 & 4 & 5 & 3 & 20 \\
\hline $\begin{array}{l}\text { The sum of the ranks of } \\
\text { each indicator } \sum_{j=1}^{r} M_{i j}\end{array}$ & 25 & 18 & 17 & 23 & 17 & $\sum_{j=1}^{r} M_{i j}=100$ \\
\hline
\end{tabular}

Starting to evaluate complex indicator of the quality of curd products, we use a 20point grading scale. The results of the average point for each sample are presented in Table 2.

Using the results of the quality assessment of of curd products and the value of weighting factors, we calculated the complex quality indicator by the formula 2 :

$$
U=\sum \_(i=1) \wedge n\left[m \_i * q \_i\right],
$$

where, qi- relative i-th indicator of product quality; mi- weight coefficient of the i-th indicator;n- number of indicators.

$$
\begin{aligned}
& \text { U1 }=0,25^{*} 5+0,18^{*} 4+0,17^{*} 3+0,23^{*} 4+0,17^{*} 3=3,91 \\
& \text { U2 }=0,25^{*} 5+0,18^{*} 4+0,17^{*} 3+0,23^{*} 3+0,17^{*} 1=3,34 \\
& \text { U3 }=0,25^{*} 5+0,18^{*} 4+0,17^{*} 3+0,23^{*} 5+0,17^{*} 3=4,14-\text { basic } \\
& \text { U4 }=0,25^{*} 4+0,18^{*} 4+0,17^{*} 2+0,23^{*} 2+0,17^{*} 2=2,86 \\
& \text { U5 }=0,25^{*} 5+0,18^{*} 4+0,17^{*} 3+0,23 * 5+0,17^{*} 3=4,14
\end{aligned}
$$

\begin{tabular}{|c|c|c|c|c|c|c|c|}
\hline № & Name of curd products & $\begin{array}{c}\text { Taste } \\
\text { and } \\
\text { smell, } \\
\text { point }\end{array}$ & $\begin{array}{l}\text { Form } \\
\text { and con- } \\
\text { sistency, } \\
\text { point }\end{array}$ & $\begin{array}{c}\text { Titrated } \\
\text { acidity, } \\
\text { point }\end{array}$ & $\begin{array}{l}\text { Amino } \\
\text { acid } \\
\text { composi- } \\
\text { tion, } \\
\text { point }\end{array}$ & $\begin{array}{l}\text { Vitamin } \\
\text { and } \\
\text { mineral } \\
\text { composi- } \\
\text { tion, } \\
\text { point }\end{array}$ & Total \\
\hline 1. & Curd product with cedar oilcake & 5 & 4 & 3 & 4 & 3 & 19 \\
\hline 2. & Curd cream & 5 & 4 & 3 & 3 & 1 & 16 \\
\hline 3. & $\begin{array}{l}\text { Curd product with cedar oilcake } \\
\text { and lactulose }\end{array}$ & 5 & 4 & 3 & 5 & 3 & 20 \\
\hline 4. & Curd cheese & 4 & 4 & 2 & 2 & 2 & 14 \\
\hline 5 & $\begin{array}{l}\text { Curd product with cedar oilcake, } \\
\text { lactulose and whey proteins }\end{array}$ & 5 & 4 & 3 & 5 & 3 & 20 \\
\hline
\end{tabular}

TABLE 2: Quality assessment results for curd products 
Thus, according to the results of the calculation of complex quality indicator, the highest value (4.14 and 3.96) was obtained for samples No. 1 - curd product enriched with cedar oil cake, No. 3 - curd product with cedar oil cake and lactulose, and No. 5 curd product with cedar oilcake, lactulose and whey proteins.

The smallest value of the integrated quality indicator (3.34 and 2.86) was obtained for samples No. 2 and No. 4 - curd cream and curd cheese, since their sponts for organoleptic indicators were reduced.

In order to assess the competitiveness of curd products, we used the following formula 3:

$$
C=C_{Q} * t+C_{E} * t
$$

where $\mathrm{C}$ - competitiveness; $\mathrm{C}_{Q}$ - quality competitiveness; $\mathrm{C}_{e}$ - competitiveness by economic indicators; $t, t$ - weighting factors of the level of quality and price of curd products for individual consumer segments.

To calculate competitiveness in terms of quality and economic indicators, we used formulas 4 and 5 .

$$
\begin{gathered}
C_{q}=\frac{U_{0}}{U}, \\
C_{e}=\frac{b}{a},
\end{gathered}
$$

where, $\mathrm{U}$ - complex indicator of the quality of the assessed sample;

$\mathrm{U}_{b}$ - complex indicator of the quality of the basic sample;

$\mathrm{C}_{a}$ - price of assessed sample;

$\mathrm{C}_{b}$ - price of basic sample.

The coefficients of the weight of the price $\left(t_{e}\right)$ and quality $(t)$ for each consumer segment are calculated by the formulas (6), (7):

$$
\begin{aligned}
& t=\frac{\frac{V_{\max }}{V_{\min }}-1}{\frac{V_{\max }}{V_{\min }}+\frac{C_{\max }}{C_{\min }}-2}, \\
& t=\frac{\frac{C_{\max }}{C_{\min }}-1}{\frac{V_{\max }}{V_{\min }}+\frac{C_{\max }}{C_{\min }}-2},
\end{aligned}
$$

The values of $\mathrm{U}_{\max }$ and $\mathrm{C}_{\max }$ correspond to their maximum values, and $\mathrm{U}_{\min }$ and $\mathrm{C}_{\text {min }}$ correspond to the minimum values in this consumer segment.

The results are presented in Table 3. 
Thus, the 1st sample is the most competitive - a curd product with cedar oil cake, which according to the calculation results has not the highest complex quality indicator (3.91) and a price slightly exceeding the cost of other samples (152.00 rubles).

Despite the highest complex quality indicator (4.14), curd products No. 3 and No. 5 with cedar oil cake and lactulose and cedar oil cake, lactulose and whey proteins are less competitive (1.0 and 0.99, respectively), and their price is higher (165.00 and 166.00 rubles, respectively) than the price of other curd products.

TABLE 3: Indicators of competitiveness $(C)$, a complex indicator of quality $(U)$ and price $(C)$ of curd products

\begin{tabular}{|l|l|c|c|c|} 
№ & Name of curd products & $\begin{array}{c}\text { complex indicator } \\
\text { of quality, U }\end{array}$ & $\begin{array}{c}\text { Price for } 1 \mathrm{~kg}, \text { rub., } \\
\text { Competitiveness, }\end{array}$ \\
\hline 1. & Curd product with cedar oilcake & 3,91 & 152,00 & 1,06 \\
\hline 2. & Curd cream & 3.34 & 148,00 & 1,03 \\
\hline 3. & $\begin{array}{l}\text { Curd product with cedar oilcake and } \\
\text { lactulose }\end{array}$ & 4,14 & 165,00 & 1,00 \\
\hline 4. & Curd cheese & 2,86 & 145,00 & 1,02 \\
\hline 5. & $\begin{array}{l}\text { Curd product with cedar oilcake, } \\
\text { lactulose and whey proteins }\end{array}$ & 4,14 & 166,00 & 0,99 \\
\hline
\end{tabular}

Thus, the curd products developed by us, enriched with prebiotic substances, are considered competitive in the modern market of curd products.

In order to compare the consumer qualities of curd products and calculate the benefit indicator (formula 8), we conducted a survey of 20 consumers. The survey results are presented in Table 4.

TABLE 4: Consumer Survey Results

\begin{tabular}{|c|c|c|c|c|c|c|c|c|c|c|c|c|c|c|c|c|}
\hline \multirow[t]{2}{*}{ Indicator № } & \multicolumn{15}{|c|}{ Criterion assessment, q } & \multirow[t]{2}{*}{ Total } \\
\hline & 1 & II & III & IV & V & I & II & III & IV & V & I & ॥ & III & IV & V & \\
\hline $\begin{array}{l}\text { Smell and } \\
\text { taste }\end{array}$ & 0 & 0 & 0 & 1 & 0 & 1 & 1 & 1 & 1 & 1 & 3 & 2 & 4 & 1 & 4 & 20 \\
\hline Consistency & 0 & 1 & 0 & 0 & 0 & 1 & 1 & 1 & 1 & 2 & 3 & 1 & 4 & 1 & 4 & 20 \\
\hline $\begin{array}{l}\text { Titratable } \\
\text { acidity }\end{array}$ & 0 & 0 & 0 & 0 & 0 & 1 & 1 & 2 & 1 & 2 & 3 & 2 & 3 & 1 & 4 & 20 \\
\hline $\begin{array}{l}\text { Amino Acid } \\
\text { Composition }\end{array}$ & 0 & 1 & 0 & 0 & 0 & 1 & 1 & 1 & 1 & 2 & 3 & 2 & 3 & 2 & 3 & 20 \\
\hline $\begin{array}{l}\text { Vitamin and } \\
\text { mineral } \\
\text { composition }\end{array}$ & 0 & 0 & 0 & 0 & 0 & 1 & 1 & 2 & 1 & 2 & 4 & 1 & 3 & 1 & 4 & 20 \\
\hline
\end{tabular}

${ }^{*} 0$ - does not satisfy; 0,5 - partially satisfies; 1 - completely satisfies.

$$
I=\sum_{i=1} \frac{q_{i \times m_{i}}}{N}
$$


where I -advantage indicator; $\mathrm{q}_{i}$ - expert assessment of consumer properties; $\mathrm{m}_{i}-$ number of experts who preferred the $\mathrm{i}$-th property; $\mathrm{N}$ - the number of surveyed consumers

The calculation of indicators of product advantage is carried out as follows: 1 indicator - taste and

smell, etc. by other indicators to determine the advantage of other consumer properties.

$$
\begin{aligned}
& I \text { № } 1=0 * 0+1 * 0,5+3 * 1 / 20=0,225 \\
& I \text { №2 }=0 * 0+1 * 0,5+2 * 1 / 20=0,175 \\
& I \text { №3 }=0 * 0+1 * 0,5+4 * 1 / 20=0,275 \\
& I \text { №4 }=1 * 0+1 * 0,5+1 * 1 / 20=0,125 \\
& I \text { №5 }=0 * 0+1 * 0,5+4 * 1 / 20=0,275
\end{aligned}
$$

The results are shown in Table 5.

All calculated indicators characterize the competitiveness of curd products for individual consumer properties. Using formula 9, we calculated the integral indicators of consumer properties of curd products.

$$
I=\sum c w \times I
$$

Where I - integral indicator; $\mathrm{C}_{w}$ - weight coefficient; I- advantage coefficient.

$$
\mathrm{I}_{\text {№I } I}=0,23, \mathrm{I}_{\text {№ } I I}=0,16, \mathrm{I}_{\text {№IIII }}=0,26, \mathrm{I}_{\text {№ } I V}=0,145 \text {, } \mathrm{I}_{\text {№ } V}=0,301
$$

\section{Discussion}

According to the obtained results, it can be concluded that competitive advantage belongs to sample No. 5 - a curd product enriched with cedar oil cake, lactulose syrup and whey proteins, the integral index of which is 0.301 . The second one is the curd product enriched with cedar oil cake and lactulose syrup, the integral index of which is 0.26; the integral indicator in the curd sample enriched with cedar oil cake is 0.23 . The integral indicators of curd cream and curd cheese have low values - 0.16 and 0.145 , respectively. 
TABLE 5: Comparison of advantage indicators of curd products

Name of indicator
Smell and taste
Consistency
Titratable acidity
Amino Acid Composition
Vitamin and mineral
composition

\begin{tabular}{|c|c|c|c|c|c|}
\hline \multicolumn{5}{|c|}{ Advantages of curd products, I } & $\begin{array}{c}\text { Weight } \\
\text { coeffi- } \\
\text { cient, } \\
\text { C }_{w}\end{array}$ \\
\hline №I & № II & № III & №IV & № V & \\
\hline 0,225 & 0,175 & 0,275 & 0,125 & 0,275 & 0,25 \\
\hline 0,225 & 0,125 & 0,275 & 0,125 & 0,325 & 0,18 \\
\hline 0,225 & 0,175 & 0,275 & 0,175 & 0,325 & 0,17 \\
\hline 0,225 & 0,175 & 0,225 & 0,175 & 0,275 & 0,23 \\
\hline 0,275 & 0,125 & 0,275 & 0,125 & 0,325 & 0,17 \\
\hline
\end{tabular}

\section{Conclusion}

The modern trends of the global market lead to the fact that in the struggle for the buyer, producers offer more and more new options for forms, tastes and directions. The expansion of the assortment due to the inclusion of enriched products not separately, but as a part of the general assortment of a particular food segment, transfers a healthy food product to a familiar and everyday product. Thus, the developed curd products enriched with prebiotic substances will be in demand in the modern market of curd products.

\section{Acknowledgement}

The authors express gratitude to their colleagues for their contribution and support of this research as well as to the reviewers for their valuable contribution to the manuscript and their help in paper completion.

\section{Conflict of Interest}

The authors have no conflict of interests to declare.

\section{References}

[1] Boldyreva, N. P. (2019). The Theory of Competitiveness Assessment: A Training Manual. Moscow: FLINT.

[2] Vytovtov, A. A. (2010). Theoretical and Practical Principles of Organoleptic Analysis of Food. St. Petersburg: GIORD. 
[3] Gorbashko, E. A. (2001). Quality and Competitiveness Management: A Training Manual. St. Petersburg: State University of Economics and Finance.

[4] Eremeeva, N. (2017). Competitiveness of Goods and Services: A Textbook. Moscow: Yurayt Publishing House.

[5] Ershov, A. K. (2016). Product Quality Management: A Training Manual. Moscow: Logos.

[6] Kvasnikova, V. V. (2015). Competitiveness of Goods and Organizations. Workshop. Moscow: Infra-M.

[7] Clopova, A. V. (2019). Calculation of the Competitiveness of Cottage Cheese. Presented at All-Russian Correspondence Scientific and Practical Conference "Innovative Ways to Solve Actual Problems of the Agro-Industrial Complex of Russia”, July 2021, Rostov-on-Don, Russia. Persianovsky: Donskoy GAU.

[8] Clopova, A. V. (2009). Development of Technology for Cottage Cheese Products Enriched with Prebiotics of Animal and Vegetable Origin. Stavropol: Cand. Tech. Sciences.

[9] Lifits, I. M. (2009). Formation and Assessment of the Competitiveness of Goods and Services: A Training Manual. (2nd ed.). Moscow: Economics.

[10] Magomedov, S. (2016). Product Quality Management: Textbook. Moscow: Dashkov and Co.

[11] Paramonova, T. N. (2016). Methodology for Calculating the Competitiveness of Goods. Retrieved from http://chp.com.ua/all-news/item/41289-metodika-raschetakonkurentosposobnosti-tovara, accessed 04.02.2021.

[12] Raikova, E. Y. (2017). Theoretical Foundations of Commodity Science and Expertise: Textbook. Retrieved from https://e.lanbook.com/book/93515, accessed 04.02.2021.

[13] Umarova, N. N. (2016). Statistical Acceptance Control of Product Quality: A Training Manual. Kazan: KNITU.

[14] Fathutdinov, R. A. (2013). Competitiveness: Economics, Strategy, Management. Moscow: INFRA-M.

[15] Nezhnikova, E. V., Chernyaev, M. V. and Papelnyuk, O. V. (2019). Economics of Quality: Textbook. Moscow: Dashkov and K. 